\title{
Rekonstruksi Asas Equality Before The Law Dalam Pemberian Bantuan Hukum Bagi Masyarakat Miskin
}

\author{
Setyo Rahmat Ramadhan \\ Advokat, Ikatan Advokat Indonesia, Kota Malang, Indonesia \\ Email: setyorahmad313@yahoo.co.id
}

Abstrak: Dalam mewujudkan asas persamaan di hadapan hukum (equality before the law) dan pemberian jasa hukum serta pembelaan bagi semua orang dalam kerangka keadilan untuk semua orang. Tujuan penelitian ini untuk mengetahui bentuk pemberian bantuan hukum terhadap masyarakat miskin berdasarkan asas equality before the law dalam mewujudkan keadilan sosial. Dengan jenis penelitian yang digunakan adalah penelitian hukum normative dengan Pendekatan peraturan perundang-udangan, Konseptual (conceptual approach) dan sosiologi. Sedangkan Analisis data yang dilakukan sebagai bahan hukum adalah merupakan dengan cara mengumpulkan seluruh bahan-bahan hukum. Hasil Penelitian ini menunjukan bahwa asas (equality before the law dalam bantuan hukum diperlukan diberikan kepada masyarakat miskin, hal ini berdasarkan pada Pasal 28D ayat (1) Undang-Undang Dasar 1945, yaitu bahwa setiap orang berhak atas pengakuan, jaminan, perlindungan, dan kepastian hukum yang adil serta perlakuan yang sama di hadapan hukum. Undang-undang Nomor 16 Tahun 2011 tentang Bantuan Hukum, yaitu bantuan hukum adalah jasa hukum yang diberikan oleh lembaga bantuan hukum atau organisasi kemasyarakatan yang memberi layanan bantuan hukum kepada orang miskin. Kemudian Seorang advokat tetap wajib memberikan bantuan hukum cuma-cuma kepada pencari keadilan yang tidak mampu sesuai dengan Undang-Undang Nomor 18 Tahun 2003 tentang Advokat.

Kata Kunci: Equality; Bantuan hukum; Masyarakat Miskin

Abstract: In realizing the of the principle of equality before the law (equality before the law) and the provision of legal services and defense for all people within the framework of justice for 
everyone. The purpose of this study was to determine the form of providing legal aid to the poor based on the principle of equality before the law in realizing social justice. The type of research used is normative legal research with a statutory, conceptual approach and sociology approach. Meanwhile, data analysis is carried out as legal material by collecting all legal materials. The results of this study indicate that the principle (equality before the law in legal aid is needed to be given to the poor, this is based on Article 28D paragraph (1) of the 1945 Constitution, namely that everyone has the right to recognition, guarantee, protection, and certainty. fair law and equal treatment before the law. Law Number 16 of 2011 concerning Legal Aid, namely legal aid is legal services provided by legal aid institutions or community organizations that provide legal aid services to the poor. Then a permanent advocate obliged to provide free legal assistance to justice seekers who cannot afford it in accordance with Law Number 18 of 2003 concerning Advocates.

Keywords: Equality; Legal assistance; Poor society

\section{PENDAHULUAN}

Dalam pasal 28D ayat (1) Undang-Undang Dasar 1945, yaitu bahwa setiap orang berhak atas pengakuan, jaminan, perlindungan, dan kepastian hukum yang adil serta perlakuan yang sama di hadapan hukum. Sehingga bantuan hukum dapat diartikan secara luas sebagai upaya untuk membantu golongan yang tidak mampu dalam bidang hukum. Sedangkan dalam pengertian sempit adalah jasa hukum yang diberikan secara cuma-cuma kepada klien yang tidak mampu. Dengan demikian akses bantuan hukum Nonstruktural, sebagai upaya dalam menjamin keadilan bagi seluruh rakyat Indonesia.

Urgensi Pemberian Layanan Bantuan Hukum untuk masyarakat marginal ini merujuk pada minimnya akses keadilan bagi masyarakat. Minimnya akses ini disebabkan oleh (1) akibat ketimpangan struktur ekonomi, politik, sosial dan budaya; Ketidaktahuan masyarakat marginal akan sistem hukum dan 
prosedur hukumnya atau buta hukum; (2) Tingginya tingkat korupsi di lembaga peradilan yang menyebabkan masyarakat marjinal tidak mampu membayar proses hukum; (3) Tidak terlaksana secara efektif kebijakan jasa bantuan hukum melalui profit; (4) Peraturan perundang-undangan yang tidak berpihak pada masyarakat miskin. ${ }^{1}$

Kewajiban membela orang miskin bagi profesi advokat tidak lepas dari prinsip persamaan dihadapan hukum dan hak untuk didampingi advokat atau penasehat hukum untuk semua orang tanpa terkecuali. Hal ini dilakukan dalam menjamin adanya persamaan dihadapan hukum (equality before the law), demikian pula hak untuk didampingi advokat dijamin sistem hukum Indonesia. Bantuan hukum yang ditujukan kepada orang miskin, memiliki hubungan erat dengan upaya untuk menjamin keadilan bagi semua. Implementasi bantuan hukum non struktural yang selama ini tidak maksimal bagi masyarakat, dipengaruhi oleh beberapa hal sehingga penerapan asas equality before the law menjadi tidak terlaksana secara baik, sehingga dalam menjamin keadilan bagi seluruh masyarakat Indonesia tidak bisa terwujud dalam kehidupan masyarakat.

Bantuan hukum meliputi menjalankan kuasa, mendampingi, mewakili, membela, dan/ atau melakukan tindakan hukum lain untuk kepentingan hukum. Pelaksanaan pemberian bantuan hukum menurut Undang-undang Nomor 16 Tahun 2011 tentang Bantuan Hukum, Bantuan Hukum hanya dilakukan oleh pemberi bantuan hukum yang telah Persyaratan untuk pemberi bantuan berbadan hukum, kantor yang tetap, memenuhi persyaratan. Dapat disebut sebagai hukum antara lain terakreditasi, memiliki memiliki pengurus, dan mempunyai program bantuan hukum. Dalam UndangUndang Nomor 18 Tahun 2003 tentang advokat. Pemberian bantuan hukum oleh pemberi bantuan hukum seperti yang telah dipaparkan diatas tidak menghapuskan kewajiban bagi seorang advokat untuk memberikan jasa bantuan hukum secara cuma-cuma. Seorang

\footnotetext{
1. Ahmad Muntolib and Sri Endah Wahyuningsih, Peran Bantuan Hukum Dalam Proses Peradilan Pidana Di Kabupaten Blora, (Jurnal Hukum Khaira Ummah 12, no. 3, (2017), 637-642.
} 
advokat tetap wajib memberikan bantuan hukum cuma-cuma kepada pencari keadilan yang tidak mampu sesuai dengan UndangUndang Nomor 18 Tahun 2003 tentang Advokat. Advokat dalam mengurus perkara cuma-cuma harus memberikan perhatian yang sama seperti terhadap perkara untuk mana ia menerima uang jasa. Beradasarkan latar belakang masalah diatas dapat di rumuskan masalah dalam bentuk rumusan masalah yakni bagaiaman bentuk pemberian bantuan hukum Terhadap Masyarakat Miskin Berdasarkan Asas Equality Before The Law dalam mewujudkan keadilan sosial.?

\section{METODE}

Dalam penelitian ini menggunkan jenis penelitian yuridis normatif yakni penelitian inventarisasi hukum positif, menemukan asas dan doktrin hukum, singkronisasi peraturan perundangundangan yang ada dan melakukan penelitian dengan mengkaji dan menelaah serta menelusuri berbagai literature yang ada. Dengan Pendekatan Konseptual (conceptual approach) yaitu pendekatan yang di lakukan dengan mengkaji konsep-konsep, teori-teori dan pendapat para ahli yang ada kaitannya denga objek yang di teliti. Pendekatan Konseptual (Conceptual Approach) yakni pandangan atau doktrin yang berkembang dalam ilmu hukum dapat menjadi pijakan untuk membangun argumentasi hukum ketika menyelesaikan isu hukum yang di hadapi. ${ }^{2}$ Sedangkan Analisis data yang dilakukan sebagai bahan hukum adalah merupakan dengan cara mengumpulkan seluruh bahan-bahan hukum, setelah isu penelitian telah ditetapkan, begitu isu hukum sudah di tetapkan peneliti melakukan penelusuran untuk mencari bahan-bahan hukum yang relefan dengan isu yang dihadapi. ${ }^{3}$

\section{HASIL DAN PEMBAHASAN}

Bantuan hukum struktural mengasumsikan bahwa kemiskinan masyarakat lebih dikarenakan kondisi struktural yang timpang.

2. Irwansyah, (2021) Penelitian Hukum Pilihan Metode \& Praktik Penulisan Artikel, Mirra Buana Media, Yogyakarta, Hal 133-152

3 . Peter Mahmud Marzuki, 2014, Penelitian Hukum, Kencana Prenadamedia Grup, Jakarta, Hal 237 
Apabila paradigma lama bantuan hukum hanya bertumpu pada bantuan hukum melalui jalur hukum saja, tanpa didukung oleh pendekatan yang bercorak struktural, maka gerakan bantuan hukum tidak akan efektif, maka strategi bantuan melalui jalur hukum wajib didukung oleh suatu gerakan yang meruntuhkan ketimpangan tersebut. Kajian ini membahas problematika pemberian bantuan hukum bagi masyarakat dan bagaimana refleksi asas equality before the law melalui pemberian bantuan hukum struktural dan non struktural.

Pemberian bantuan hukum struktural dan non struktural dipengaruhi oleh kerangka hukum normative pemberian bantuan hukum yang tidak bekerja, dll, sedangkan refleksi asas equality before the law berkaitan dengan pemberian bantuan hukum struktural dan non struktural ini sudah dimuat dalam pasal 28D ayat (1) Undang-Undang Dasar 1945, yaitu bahwa setiap orang berhak atas pengakuan, jaminan, perlindungan, dan kepastian hukum yang adil serta perlakuan yang sama di hadapan hukum. Asas ini sebagai prinsip yang sangat vital dalam pemberian bantuan hukum struktural dan non struktural, hal Ini juga merupakan konsekuensi Negara Indonesia sebagai negara hukum (pasal 1 ayat (3) UUD 1945). ${ }^{4}$

Bantuan hukum kesejahteraan diartikan sebagai suatu hak akan kesejahteraan yang menjadi bagian dari kerangka perlindungan sosial yang diberikan oleh suatu Negara kesejahteraan. Bantuan hukum kesejahteraan sebagai bagian dari haluan sosial diperlu- kan guna menetralisir ketidakpastian kemiskinan. Karena itu pengembangan sosial atau perbaikan sosial selalu menjadi bagian dari pelaksanaan bantuan hukum kesejahteraan. Dalam Undang-undang Nomor 16 Tahun 2011 tentang Bantuan Hukum, pengertian bantuan hukum lebih mengarah kepada legal aid. Ini bisa dilihat dari definisi yang diberikan oleh Undang-undang tersebut, yaitu bantuan hukum

\footnotetext{
4 . Ni Gusti Agung Ayu Mas Triwulandari, Problematika Pemberian Bantuan Hukum Struktural Dan Non Struktural Kaitannya Dengan Asas Equality Before The Law, Jurnal Ilmiah Kebijakan Hukum, Volume 14, Nomor 3, November 2020: 539-552
} 
adalah jasa hukum yang diberikan oleh lembaga bantuan hukum atau organisasi kemasyarakatan yang memberi layanan bantuan hukum kepada orang miskin. Bagi masyarakat awam, besar kemungkinan terdapat kerancuan pemaknaan antara pengertian bantuan hukum secara umum dengan pengertian bantuan hukum yang dimaksud bahwa Pemberian bantuan hukum secara cumacuma atau yang lebih dikenal sebagai bantuan hukum pro bono (pro bono publico) atau legal aid adalah suatu upaya untuk mencapai keadilan bagi semua orang.

Ruang lingkup Bantuan hukum meliputi menjalankan kuasa, mendampingi, mewakili, membela, dan/ atau melakukan tindakan hukum lain untuk kepentingan hukum. Pelaksanaan pemberian bantuan hukum menurut Undang-undang Nomor 16 Tahun 2011 tentang Bantuan Hukum, Bantuan Hukum hanya dilakukan oleh pemberi bantuan hukum yang telah Persyaratan untuk pemberi bantuan berbadan hukum, kantor yang tetap, memenuhi persyaratan dapat disebut sebagai hukum antara lain terakreditasi, memiliki memiliki pengurus, dan mempunyai program bantuan hukum. Selain diatur dalam Undang-undang Nomor 16 Tahun 2011 tentang Bantuan Hukum, pemberian bantuan hukum pro bono juga diatur dalam Undang-Undang Nomor 18 Tahun 2003 tentang advokat. Pemberian bantuan hukum oleh pemberi bantuan hukum seperti yang telah dipaparkan diatas tidak menghapuskan kewajiban bagi seorang advokat untuk memberikan jasa bantuan hukum secara cuma-cuma. Seorang advokat tetap wajib memberikan bantuan hukum cuma-cuma kepada pencari keadilan yang tidak mampu sesuai dengan Undang-Undang Nomor 18 Tahun 2003 tentang Advokat. Advokat dalam mengurus perkara cumacuma harus memberikan perhatian yang sama seperti terhadap perkara untuk mana ia menerima uang jasa.

Sementara Kemiskinan struktural berarti pula adanya pola hubungan yang mendasari kehidupan di masyrakat dan mempertahankan kemiskinan. Oleh karena itu, bantuan hukum structural akan merupakan kegiatan yang bertujuan untuk menciptakan kondisi-kondisi bagi terwujudnya hukum yang mampu 
merubah struktur yang lebih adil, tempat peraturan hukum dan pelaksanaannya menjamin persamaan kedudukan baik dilapangan politik berarti hukum maupun dilapangan ekonomi. Ini pelaksanaan dan pengembangan dilihat dari sudut bantuan hukum struktural harus dilaksanakan dalam konteks untuk membangun masyarakat yang adil dan makmur. ${ }^{5}$

Kerangka hukum normatif mengenai pemberian bantuan hukum dalam tataran praktik di masyarakat, terutama pada konstituen regulasi tersebut yaitu rakyat miskin masih belum dijalankan secara optimal oleh para advokat sebagai salah satu pemberi bantuan hukum. Terdapat tiga hal perilaku advokat dalam menghadapi persoalan bantuan bagi rakyat miskin yaitu menghindari dengan berbagai alasan, menerima perkara dengan syarat perkara tersebut harus menarik media massa sehingga menaikkan pamor advokat, dan yang terakhir menerima hukum yang telah Persyaratan untuk pemberi bantuan berbadan hukum, kantor yang tetap, memenuhi persyaratan. dapat disebut sebagai hukum antara lain terakreditasi, memiliki memiliki pengurus, dan mempunyai program bantuan hukum.

Selain diatur dalam UU tentang Bantuan Hukum, pemberian bantuan hukum pro bono juga diatur dalam Undang-Undang Nomor 18 Tahun 2003 tentang advokat. Pemberian bantuan hukum oleh pemberi bantuan hukum seperti yang telah dipaparkan diatas tidak menghapuskan kewajiban bagi seorang advokat untuk memberikan jasa bantuan hukum secara cuma-cuma. Seorang advokat tetap wajib memberikan bantuan hukum cuma-cuma kepada pencari keadilan yang tidak mampu sesuai dengan Undang-Undang Nomor 18 Tahun 2003 tentang Advokat. Advokat dalam mengurus perkara cuma-cuma harus memberikan perhatian yang sama seperti terhadap perkara untuk mana ia menerima uang jasa. Sepenuhnya melakukan pemberian bantuan hukum. Para sebagian advokat lebih cenderung menyukai membela para klien menengah keatas

\footnotetext{
5 . M. Yahya Harahap, (2003) Pembahasan Permasalahan dan Penerapan KUHAP, Penyidik dan Penuntut, Cet. Ke-5, Jakarta ; Sinar Grafika, Jakarta, Hal 22
} 
ketimbang rakyat miskin, hal ini bisa mereduksi profesi advokat sebagai profesi mulia menjadi profesi komersil. ${ }^{6}$

Ketidaktahuan akan hukum meng-akibatkan seseorang akan melanggar hukum akan atau seseorang tersebut dibodohi oleh oknum untuk mengambil keuntungan, dan yang lebih mencengangkan adalah oknum tersebut biasanya dari kalangan penegak hukum ataupun pemerintah. Sebab ketika kerangka normatif pemberian bantuan hukum tidak di jalankan oleh advokat maka hukum mengenai bantuan hukum tersebut tidaklah menjadi hukum dengan kata lain regulasi mengenai bantuan hukum hanyalah mitos yang dibuat oleh negara. ${ }^{7}$

Bahwasanya bantuan hukum structural dan non struktural adalah suatu konsep untuk mewujudkan persamaan di hadapan hukum (equality before the law) dan pemberian jasa hukum serta pembelaan bagi semua orang dalam kerangka keadilan untuk semua orang. Refleksi asas equality before the law berkaitan dengan pemberian bantuan hukum struktural dan non struktural ini sudah dimuat dalam pasal 28D ayat (1) Undang-Undang Dasar 1945, yaitu bahwa setiap orang berhak atas pengakuan, jaminan, perlindungan, dan kepastian hukum yang adil serta perlakuan yang sama di hadapan hukum. Asas ini sebagai prinsip yang sangat vital dalam pemberian bantuan hukum structural dan non struktural, hal Ini juga merupakan konsekuensi Negara Indonesia sebagai negara hukum (pasal 1 ayat (3) UUD 1945 hasil perubahan ketiga). Ada tiga prinsip negara hukum (rechstaat), yaitu supremasi hukum (supremacy of law), kesetaraan di hadapan hukum (equality before the law), dan penegakan hukum dengan cara-cara yang tidak bertentangan dengan hukum (due process of law).

Pemberian bantuan hukum kepada masyarakat miskin buta hukum dan tertindas ditujukan tidak lain dan tidak bukan adalah

6. Marudut Tampubolon, (2014) Membedah Profesi Advokat, Perspektif IImu Sosial Interaksi AdvokatKlien, Yogyakarta : Pustaka Pelajar, Hal 11

7 . Suyogi Imam Fauzi and Inge Puspita Ningtyas, Optimalisasi Pemberian Bantuan Hukum Demi Terwujudnya Access to Law and Justice Bagi Rakyat Miskin, (Jurnal Konstitusi 15, no. 1 2018) 50-72 
untuk memberikan acces to justice merupakan refleksi asas equality before the law. Dalam praktiknya, pendampingan bagi masyarakat miskin menjadi sebuah tugas yang diharuskan dalam mencari keadilan bukan berdasarkan atas hati nurani. Kondisinya saat ini, asas equality before the law belum dijadikan patokan utama dalam pemberian bantuan hukum. Padahal, jika secara benar dan patut asas ini direfleksikan ke dalam penegakan hukum di Indonesia, seyogyanya tidak ada lagi masyarakat miskin mengalami diskriminasi dan ketidakadilan hukum.

\section{PENUTUP}

Dalam merekonstruksi asas persamaan di hadapan hukum (equality before the law) dan pemberian jasa hukum serta pembelaan bagi semua orang dalam kerangka keadilan untuk semua orang. Maka bantuan hukum diperlukan diberikan kepada masyarakat miskin, hal ini berdasarkan pada Pasal 28D ayat (1) Undang-Undang Dasar 1945, yaitu bahwa setiap orang berhak atas pengakuan, jaminan, perlindungan, dan kepastian hukum yang adil serta perlakuan yang sama di hadapan hukum. Semenatra dalam Undang-undang Nomor 16 Tahun 2011 tentang Bantuan Hukum, pengertian bantuan hukum lebih mengarah kepada legal aid. Ini bisa dilihat dari definisi yang diberikan oleh Undang-undang tersebut, yaitu bantuan hukum adalah jasa hukum yang diberikan oleh lembaga bantuan hukum atau organisasi kemasyarakatan yang memberi layanan bantuan hukum kepada orang miskin. Kemudian Seorang advokat tetap wajib memberikan bantuan hukum cumacuma kepada pencari keadilan yang tidak mampu sesuai dengan Undang-Undang Nomor 18 Tahun 2003 tentang Advokat. Advokat dalam mengurus perkara cuma-cuma harus memberikan perhatian yang sama seperti terhadap perkara untuk mana ia menerima uang jasa. Sepenuhnya melakukan pemberian bantuan hukum. Para sebagian advokat lebih cenderung menyukai membela para klien menengah keatas ketimbang rakyat miskin, hal ini bisa mereduksi profesi advokat sebagai profesi mulia menjadi profesi komersil. 


\section{DAFTAR PUSTAKA}

Ahmad Muntolib and Sri Endah Wahyuningsih, Peran Bantuan Hukum

Dalam Proses Peradilan Pidana Di Kabupaten Blora, (Jurnal Hukum Khaira Ummah 12, no. 3,(2017), 637-642.

Irwansyah, (2021) Penelitian Hukum Pilihan Metode \& Praktik Penulisan Artikel, Mirra Buana Media, Yogyakarta, Hal 133-152

Peter Mahmud Marzuki, 2014, Penelitian Hukum, Kencana Prenadamedia Grup, Jakarta, Hal 237

M. Yahya Harahap, (2003) Pembahasan Permasalahan dan Penerapan KUHAP, Penyidik dan Penuntut, Cet. Ke-5, Jakarta ; Sinar Grafika, Jakarta, Hal 22

Marudut Tampubolon, (2014) Membedah Profesi Advokat, Perspektif Ilmu Sosial Interaksi AdvokatKlien, Yogyakarta : Pustaka Pelajar, Hal 11

Ni Gusti Agung Ayu Mas Triwulandari, Problematika Pemberian

Bantuan Hukum Struktural Dan Non Struktural Kaitannya Dengan Asas Equality Before The Law, Jurnal Ilmiah Kebijakan Hukum, Volume 14, Nomor 3, November 2020: 539-552

Suyogi Imam Fauzi and Inge Puspita Ningtyas, Optimalisasi Pemberian Bantuan Hukum Demi Terwujudnya Access to Law and Justice Bagi Rakyat Miskin, (Jurnal Konstitusi 15, no. 1 2018) 50-72 